\title{
Clickers, en \\ læringsunderstøttende ressource?
}

\author{
Helle Mathiasen, Professor, Center for it og laring, Aarhus Universitet
}

\section{Reviewet artikel \\ Clickers er de seneste år blevet brugt specielt indenfor science- fag på danske universiteter. Med fokus på studerendes tilgang til clickerbrug ifysikundervisning diskuteres hvornä, hvordan og på hvilke promisser clickers kan vare en ressource for studerende og undervisere. \\ Artiklens overordnede konklusion er, at clickerbrug kan fremstå som en kommunikations- og laringsunderstottende ressource, men at omfanget af nyttevardi afhoenger af un- dervisernes padagogiske og didaktiske tilgange og formåen samt de studerendes tilgange til kommunikativ deltagelse $i$ undervisningen.}

\section{Indledning}

I flere år har clickers, også benævnt »Electronic Voting Systems", "Audience Paced Feedback «, "Classroom Communication« og "Student Response Systems", "Audience Response Systems", "voting-machines", "zappers" og "Classrooms Response Systems", været en ressource, som universitetsundervisere har brugt, specielt inden for de naturvidenskabelige fag. (Bruff, 2011; Fies et al, 2006; MacArthur, J. R. et al, 2008). I Danmark går clickers også under betegnelsen stemmeklodser. Der er i princippet to forskellige typer, hvor den ene type udelukkende kan stemme via seks taster. Den anden type minder mere om en mobiltelefon, hvor der er en lille skærm og et tastatur, hvor der er mulighed for både at skrive tal og bogstaver. Udover et antal clickers kræves en computer til opsamling af clickersvarerne samt en tavle til visning af spørgsmål, stemmeafgivelser og grafiske fremstillinger af afstemningen.

Der findes i skrivende stund ikke publiceret forskningsbaseret litteratur om clicker-anvendelser i danske universitetsuddannelser, og da flere undervisere på danske universiteter, primært inden for de naturvidenskabelige fag, har anvendt clickers i deres undervisning de seneste år, synes det relevant at starte en udfoldelse af dette felt. Med et casestudie inden for fysikundervisning på to danske universiteter, (2010-2011) vil artiklen præsentere et konkret empirisk studie med det formål at få viden om, hvordan clicker-brug kan blive inddraget $\mathrm{i}$ undervisningen, og hvilke tilgange studerende har til denne brug. Artiklens empiriske fokus er de studerendes tilgang til undervisning, hvor clickers indgår som en ressource. Denne del af artiklen bygger på informationer indsamlet via observationer af undervisning, gruppeinterview og opfølgende samtaler med underviserne.

Den begrebsmæssige optik tager udgangspunkt $i$ et systemteoretisk inspireret kommunikationsbegreb og en definition på undervisning som en særlig form for kommunikation, der intenderer forandring. På baggrund af en kort state of the art præsentation af litteraturen om clickerbrug i universitetsregi samt casestudiets rammesætning diskuteres findings i den anlagte systemteoretiske optik.

\section{Litteratur om clickerbrug i sciencefag}

De fleste publikationer beskæftiger sig med brugen af clickers i forbindelse med forelæsninger og dermed ofte større hold af studerende og er primært produceret $i$ USA. (fx Fies et al, 2006; MacArthur, J. R. et al, 2008; Caldwell, 2007; Barber et al 2007). Publikationer fortæller om læringspotentialer, men det halter med forsk- 
ningsmæssigt belæg, der kan konkludere, at clickers i sig selv har en øget læringseffekt (Caldwell, 2007). Nogle forskere stiller spørgsmålet, om flashcarts giver et andet læringsudbytte end clickers. Fx konkluderes at der ikke er forskel på læringsudbyttet for studerende, der brugte clickers sammenlignet med studerende, der brugte flashcarts (Lasry, 2008). Det er ikke teknologien i sig selv, der gør en forskel men den pædagogiske og didaktiske tilgang til undervisning, og ideen om at engagerede og kommunikativt aktive studerende er en afgørende faktor, når det drejer sig om frugtbare undervisningsmiljøer. En anden undersøgelse (hvor forsker også var underviseren) viser, at hold, hvor der blev brugt clickers, klarede sig bedre i de standardiserede fysiktests end kontrolgruppen uden clickers. (Mazur et al, 2001) Undersøgelserne er oftest bundet op på let målbare metoder og primært på surveys og testresultater (Fies, 2006).

Publikationerne fremhæver de studerendes mulighed for at kommunikere om svarmulighederne med hinanden i mindre grupper i forbindelse med afstemningerne. Intentionen er mere interaktion og aktivt deltagende studerende. Nogle plæderer for "peer-discussion" efter stemmeafgivelser før anden afstemning (Mazur, 1997) - andre foretrækker en model, hvor de studerende først diskuterer i små grupper og derefter stemmer (Dufresne, 1996).

Test, kontrol og "credits" er temaer, der ofte dukker op i litteraturen (fx MacArthur, 2008, Fies, 2006). Mulighederne for at registrere hvem, der svarer hvad og individuel svarfrekvens ses som kerneydelser. En af de afledte diskussioner i litteraturen går på, hvor mange point ("credits") studerende skal registreres for, hvis de stemmer forkert. Et andet afledt tema er, hvorvidt anonymitet $i$ fht. stemmeafgivelse har betydning for de studerendes stemme- og kommunikationsaktivitet. En undersøgelse viser, at de studerende bliver mere aktive og engagerede og mindre tilbageholdende, når de kan afgive svar anonymt. De studerende har ikke problemer med at diskutere i små grupper, men de er ikke begejstrede for at ytre sig, når det handler om større hold. Dette bruges som argument for brug af clickers frem for farvekort eller anden markering ( $\mathrm{fx}$ Caldwell, 2007). De studerende ønsker anonymitet såvel over for medstuderende som over for undervisere. ( $\mathrm{fx}$ Fies, 2006). De studerende finder clickerbrug »enjoyable» (Bode, M 2009), og flere publikationer fortæller om begrundelser som fastholden af opmærksomhed ( $\mathrm{fx}$ Caldwell, 2007).

\section{Teoretisk udgangspunkt}

Med systemteoriens kommunikationsbegreb som omdrejningspunkt tilbydes en særlig optik på undervisning og videnskonstruktion. Denne optik kan med fordel bruges $i$ en diskussion om clickerbrug, da kommunikationsbegrebet sætter fokus på, hvad der skal til, for at betegnelsen kommunikation kan aktualiseres. Endvidere giver begrebet mulighed for at skelne mellem meddelt information og kommunikation, hvilket er en væsentlig skelnen $i$ en diskussion om clickers $i$ undervisningen. Systemteoriens klare skelnen mellem psykiske systemer (bevidtshedsaktiviteter) og sociale systemer (kommunikative aktiviteter) samt definitionen af systemer som operativt lukkede og selvreferentielle, men ikke autarkiske - danner det teoretiske fundament for en diskussion af clickers som kommunikationsressource i sociale systemer og læringsressource $i$ fht. psykiske systemer.Yderligere anses optikken om trivielle og ikke-trivielle systemer som en frugtbar skelnen i diskussionen af clickerbrug. Læring iagttages som videnskonstruktion (psykiske systemer) og undervisning iagttaget som en særlig og specialiseret form for kommunikation (sociale systemer) er operativt lukkede for hinanden. (f.eks.Luhmann, 2000). Konsekvensen af denne tilgang er, at der ikke er tale om kausalitet og forudsigelighed, hvilket den efterfølgende inddragen af begreberne trivielle og ikke-trivielle systemer vil udfolde.

Kommunikationsbegrebet adskiller sig fra tidligere transfermodeller (fx Shannon et all, 1949/1971) ved at definere en kommunikationsenhed som en syntese af tre selektioner, hvor de to første selektioner, valg af information og meddelelsesform, foretages af »den meddelende " mens den tredje selektion, valg af forståelse, foretages af »adressat«. De første to selektioner $i$ en kommunikationsenhed bruger sprog (i bredeste forstand). Den meddelte information (de to første selektioner) kan iagttages, mens den tredje selektion, valg af forståelse, ikke kan iagttages (en bevidsthedsaktivitet). Først ved adressatens valg af efterfølgende meddelelse kan der iagttages og tilskrives en forståelsesselektion. I den forstand skal der minimum en følge af to kommunikationsenheder til, for at vi kan tale om feed-back. Yderligere er konsekvensen, at det blot at meddele noget ikke i sig selv er kommunikation. Det er her det systemteoretiske kommunikationsbegreb har en særlig udsagnskraft, idet, der fokuseres på, at det, at meddele noget i sig selv ikke er kommunikation, det at præsentere et clickerspørgsmål i sig selv ikke er kommunikation og det at clicke et svar heller ikke i sig selv kommunikation. Først når adressat retter sin opmærksomhed mod spørgsmålet eller svaret på spørgsmålet og dermed har valgt forståelse (tredje selektion) er der tale om en kommunikationsenhed. En efterfølgende stemmeafgivelse er så en ny kommunikationsenheds første to selektioner og tredje selektion er så i princippet clickerprogrammets valg af "forståelse« og pointen her er, at det i sig selv ikke understøtter videnskonstruktion, at se resultatet af en afstemning. Det afgørende i relation til clickers som læringsunderstøttende redskab er, om underviser retter sin opmærksomhed mod clickerafstemningen, for derefter at vælge $\sin$ forståelse. Underviser har dermed 
bolden i relation til kommunikationens fortsættelse og den forsatte feed-back-mulighed i forhold til de studerende.

Undervisning defineres som den særlige form for kommunikation, der har som intention at forandre, og det betyder, at undervisning iagttaget som kommunikation har som formål at "forstyrre«, give "næring" og tilbyde sig som en ramme, der muliggør igangsættelse/fortsættelse af læreprocesser. En pointe i den sammenhæng er, at den studerende kan lære sig noget, og følgelig er viften af mulige kommunikative kontekster i fokus. En følge af den præsenterede teoretiske optik er, at den enkelte studerende iagttager sin omverden med netop sin optik, som på det givne tidspunkt er muligt at aktualisere.Valg af kommunikativ forståelse er således systemspecifik. Undervisning kan i princippet resultere i lige så mange valg af forståelser af det af underviseren meddelte, som der har været studerende til stede. Et sådant kommunikations- og læringsteoretisk udgangspunkt har konsekvenser for måden at tænke undervisning på. Den anlagte systemteoretiske ramme klargør, at undervisning handler om kommunikativt at "forstyrre " deltagerne, og da der er tale om operativt lukkede selvstyrende systemer, er dette en aktivitet, der ikke som sådan har en simpel eller best-practice løsning. Den fremlagte systemteoretiske tilgang giver i stedet mulighed for at betragte kommunikation som en væsentlig faktor, når valg af undervisningsformer skal besluttes. Der skelnes mellem undervisningsorganisering (f.eks. hold og grupper) og undervisningsformer (f.eks. forelæsning og projektorganiseret gruppearbejde). Præmissen er kompleksitet, og kompleksitet "betyder selektionstvang, selektionstvang betyder kontingens, og kontingens betyder risiko (Luhmann, 2000:62).

Den introducerede tilgang mht. en kobling mellem undervisning og læring kan udfoldes med begreberne trivielle og ikke trivielle maskiner (Foerster et al, 2003), her benævnt systemer. Clickers kan i princippet understøtte begge tilgang.

Trivielle systemer er systemer, der, hvis de får et bestemt input, vil levere et forudsigeligt output (Foerster \& Pörksen, 2003). Med andre ord er trivielle systemer programmeret til at behandle input kontekstuafhængigt, således at output er pålideligt, kausalt betinget og dermed entydige sammenhænge mellem input og output. Ikke-trivielle systemer er selvreferentielle systemer, som opererer ud fra deres givne tilstand og en konkret kontekst. Ikke-trivielle systemer er således ikke pålidelige og ikke kausalt betingede. Pointen er, at en 'triviel system'- optik reducerer kompleksitet. Trivielle systemer »er indbegreb af vished og sikkerhed (Foerster \& Pörksen, 2003: 44). Er tilgangen til undervisning og læring formet af ideen om trivielle systemer, kan der med behaviorismen in mente kreeres passende input og forudsigelige output. Og det kan testes. "Tests er instrumenter til at fastslå et bestemt omfang af trivialisering. Et fremragende testresultat viser en fuldstendig trivialisering:
Eleven er helt forudsigelig og kan derfor lukkes ud $i$ samfundet« (von Foerster, 1993: 208 i Luhmann, 2006:103). Clickers kan understøtte denne tilgang, hvilket litteraturen også kan fortælle.

Systemer er med den anlagte teoretiske ramme som udgangspunkt ikke-trivielle kontekstafhængige systemer. Det betyder ikke, at de ikke kan lade sig trivialisere, jf. citaterne, men undervisningen kan i den præsenterede teoretiske optik ikke per se præstere kausale effekter. Præmissen er, at vi har med komplekse systemer at gøre. Der skal foretages didaktiske valg hvor præmissen er kontingens og risiko. Clickers kan som andre teknologier ikke "sikre", at de studerende lærer sig det intenderede, men de kan invitere til fortsat kommunikation. Undervisningsformen forelæsning og undervisningsorganiseringen (stor)hold benytter i væsentlig grad formidling, (de to første selektioner i en kommunikationsenhed). Clickers kan udfolde formidlingen, og alt efter undervisers brug af clickers, kan studerende og underviser fortløbende fă feedback og løbende afprøve forståelse af det meddelte.

Undervisningskommunikation kan fremme forståelse i den forstand, at hvis der er mulighed for løbende forståelseskontrol, så kan kommunikationen fremstå som næring til fortsat kommunikation og fortsat videnskonstruktion, men der er ingen garantier for at forståelse som intenderet også er den, der aktualiseres.

\section{Casestudie}

Studiet af clickerbrug på universiteterne er en del af et forsknings- og netværksprojekt, hvor også clickerbrug i fysiskundervisningen i det almene gymnasium (stx) er inkluderet. Artiklen omhandler udelukkende universitetsdelen af projektet. Undersøgelsen er foretaget 2010-2011.

\section{Den empiriske undersøgelse}

Der er først foretaget observationer af holdundervisning og umiddelbart efter gennemført gruppeinterview med studerende og efterfølgende samtale med underviserne. Først fremlægges korte observationsbeskrivelser og dermed den konkrete ramme, hvori clickers er blevet brugt (metodemæssigt skrevet i nutid). Derefter følger et koncentrat af gruppeinterviewene, hvor der er tilføjet få opklarende informationer, som er fremkommet under samtalerne med underviserne. Den teoretiske optik kobles til denne del af casefremstillingen.

\section{Observationer af holdundervisning}

\section{Observationseksempel 1: Foreleesning kl.8-11, 43 bachelorstuderende, traditionel bordopstilling $i$ rekker.}

Underviseren præsenterer ved start af lektionen tre clickerspørgsmål, hver med tre til fem valg som ap- 
petizer til nyt stof, som skal gennemgås i lektionen. Spørgsmålene har karakter af "intuitionsfremkaldende« svar. Der følger senere otte sæt clickerspørgsmål, der fungerer som repetition, alle med fire eller fem svarmuligheder. Underviser viser stemmeresultatet som grafik på tavle og opfordrer til diskussion mellem de studerende (parvis), hvilket de studerende tager til efterretning $i$ forbindelse med "intuitionsspørgsmålene«, men i mindre grad i forbindelse med de otte repetitionsspørgsmål. Underviser gennemgår efter hver clickerafstemning relateret teori. Få studerende har computere fremme, der lyttes og enkelte tager noter. Brugen af clicker er baseret på anonymitet.

\section{Observationseksempel 2, Forelasning kl.13-16, 20} bachelorstuderende, traditionel bordopstilling $i$ rakker.

De første clickerspørgsmål vedrører seneste forelæsningstema, de næste ti spørgsmål handler om dagens stof, og forelæsningen afsluttes med spørgsmål i næste lektion samt ti evalueringsspørgsmål (hver afstemning har tre til fem valgmuligheder). Underviser har tidligere fortalt, at de studerede først skal svare individuelt på clickerspørgsmålet. Stemmeresultatet vises grafisk på tavle. Er der ikke enighed om svarerne, beder underviser de studerende diskutere parvis. Derefter beder underviser de studerende om at afgive deres stemme igen. Har de studerende stort set alle svaret rigtigt, bliver undervisers forklaringer korte. Ofte vælger underviser her at lade en studerende forklare, hvorfor det valgte svar er rigtigt. De studerendes opmærksomhed er rettet mod undervisers kommunikation. Ingen af de studerende havde computere fremme. Brugen af clickers er baseret på ikke-anonymitet.

\section{Svarstatus efter observationerne}

I observationseksempel 1 ytrede godt $25 \%$ af de studerende sig ved håndsoprækning, mens det i observationseksempel 2 drejede sig om $50 \%$.

Der var en gennemsnitlig clickersvarprocent på henholdsvis godt $75 \%$ og knap $100 \%$. De fleste mundtlige indlæg var svar på underviserspørgsmål. Få studerende stillede spørgsmål til underviser.

Underviser i eksempel 2 valgte ikke-anonymitet, da han ville bruge informationerne til at hjælpe studerende $\mathrm{i}$ deres faglige udvikling samt indsamle statistisk materiale til egen brug.

\section{Gruppeinterview med studerende}

De studerendes overordnede erfaringer med clickerbrug var, at i holdundervisningsforløb med forelæsning som den dominerende undervisningsform

- havde undervisers pædagogiske og didaktiske tilgang stor betydning
- ville clickers kunne bruges i mange faglige sammenhænge

- skulle clickers inddrages ud fra princippet tilpas variation, både når det gjaldt den enkelte forelæsning, hele undervisningsforløb og uddannelses fagrække

- kunne clickers give øget selvtillid, motivation samt aktivitetsniveau

Deres udgangspunkt var, at undervisning skulle kunne favne faglige og pædagogiske forskelligheder og studerende med forskellige forudsætninger, potentialer og præferencer. Med den anlagte teoretiske optik iagttages et ønske fra de studerende om, at underviser tænker $\mathrm{i}$ ikke-trivielle systemer og dermed ikke i en tænkning, der søger trivialiseringer af undervisningen og dens deltagere, men netop giver de studerende mulighed for fortløbende afprøvning af deres forståelse i forskellige kommunikative kontekster.

\section{Feedback}

Der var blandt de studerende enighed om at clickers gav øgede og nyttige muligheder for feed-back og refleksion for såvel dem selv som for underviserne, her med fokus på det faglige stof og undervisningspraksis. Der kan udvaskes følgende feedback - former og præmisser:

- individuelle svar på clickerspørgsmål uden dialog med medstuderende

- individuelle svar på clickerspørgsmål efter dialog med medstuderende

- afstemningsresultat og efterfølgende udfoldelse af stoffet $\mathrm{v} /$ underviser eller studerende

- afstemningsresultat og efterfølgende individuel vejledning

- afstemningsresultat (som information til underviser og studerende, men uden opfølgning fra underviser)

Sidste pind, som i den teoretiske optik kunne kaldes den simple feed-back, så de studerende som en mulighed, men de pointerede, at det var vigtigt, at alle så havde svaret rigtigt: "Det forringer undervisningen, hvis clickers kun bliver brugt til at clicke svar, og så er det det. Det er argumentationen over for hinanden, der er godt". Dette kan ses som udtryk for, at de studerende ikke ønsker en trivialisering af undervisningen, men i stedet muligheden for via kommunikation at afprøve egen forståelse.

\section{Tempo}

Den enkelte afstemning må ikke vare for længe "så er det, at undervisningen går $i$ stå, og man begynder så at toenke på andre ting. "Nogle studerende mente dog, at de havde for kort tid til at tænke sig om, hvilket kunne resultere $\mathrm{i}$, at de blot gættede. De studerende var enige om, at "folk bliver holdt til ilden". De mente, at en forelæsning med fordel kunne tilrettelægges med to sæt af max seks spørgsmål. Tidsaspektet blev tematiseret i 
forbindelse med aktiviteter efter afstemningerne. De studerende pointerede, at det var optimalt med forklaring og diskussion umiddelbart efter afstemningen. "Hvis man venter til noeste gang, så glemmer man sporgsmålet, ens egne argumenter og de argumenter, der var fremme". Tidsdimensionen optræder således som en væsentlig parameter i forhold til kommunikationens og læringens fortsatte proces.

\section{Sporgsmål}

De studerende var enige om, at følgende typer af spørgsmål var væsentlige at veksle imellem:

- Faktuelle spørgsmål

- Repetitionsspørgmål

- Intuitionsinviterende spørgsmål

- Diskussionsinviterende spørgsmål

- Appetizer-spørgsmål

Konceptuelle spørgsmål indgik i primært de sidste fire typer spørgsmål.

De studerende havde erfaringer med clickerbrug som noget, der kunne give men mere intuitiv forstålse af det teoretiske stof", og at det krævede, at underviserne havde fokus på mulighederne. Det var ikke alle undervisere, der formåede at formulere gode clickerspørgsmål og følge kommunikativt op på deres spørgsmål. De studerende mente, at det hang sammen med undervisernes undervisningskompetencer. De studerende var enige om, at ikke alle undervisere havde reflekteret over deres brug af clickers $i$ undervisningen og fortæller, at den gode underviser kunne have glæde af at bruge clickers og dermed forbedre undervisningen, mens en dårlig underviser ikke blev en bedre underviser af at bruge clickers, "universitetsundervisere mangler det peedagogiske«. Det skal nævnes, at underviserne i de to præsenterede observationseksempler blev rost af de studerende.

\section{Anonymitet - ikke anonymitet}

Der kan overordnet skelnes mellem anonymitetskategorierne ikke-anonymitet og anonymitet, og dermed om studerende som meddeler kan identificeres. Dernæst kan der skelnes mellem koblingen af disse kategorier til underviser og medstuderende.Yderligere kan der groft skelnes mellem undervisers grundlæggende tilgang til brug af clickersvar som kommunikations-/ læringsressource og som kontrol, test samt kursuspointgivende. Med andre ord kan denne skelnen ses som præmis for adressats (underviser) tilgang til clickersvar fra studerende - og meddelers (studerende) tilgang til afgivelse af clickersvar.

Intentionen fra underviser, der havde valgt ikkeanonymitet, var at få mulighed for at kunne identificere den enkelte studerende og dermed kunne følge op på dennes faglige udvikling, hvilket ville kunne ske på et nyt informationsfunderet niveau. De studerende så ikke ikke-anonymitet i forhold til underviser som et problem, men som en ressource, der gav underviser "mulighed for at se, hvordan den enkelte udvikler sig" og de havde forventninger om, at underviser ville bruge denne viden til f.eks. individuel vejledning. De pointerede, at det ikke var underviser, de ikke ville dumme sig over for, men "hvis man sidder $i$ en sal med 200 mennesker, er man jo ikke så meget for at rekke hånden op, hvis man ikke er sikkerw. De skelner således mellem anonymitet $\mathrm{i}$ forhold til underviser og anonymitet $\mathrm{i}$ fht medstuderende. Sidstnævnte kategori indebærer, at kommunikationens 1. og 2. selektion ikke kan iagttages, og dermed er der tale om en speciel form for kommunikation, hvor den enkelte meddelelse af information (clickersvaret) ikke kan tematiseres. Det har, som de studerende påpegede, fordele. Med den systemteoretiske tilgang kan det dog også ses som en ulempe, hvis de kommunikative bidrag fra studerende udelukkende går gennem clickers. Holdet, som socialt system, kan så at sige miste kommunikative muligheder, hvis der ikke inviteres til mundtlige indlæg og diskussioner.

De studerende mente ikke, at clickers skulle bruges til fortløbende kontrol og test, "det vil vere superstressende« og "Man skal også have lov til at svare forkert". De så clickers som en ressource for dem, hvor det at svare var en mulighed for at forholde sig til det faglige stof. De pointerede, at de også lærte af at afgive forkerte clickersvar og værdsatte den information, der fremkom efter endt afstemning, da de bl.a. satte pris på at kunne måle sig i forhold til de øvrige studerende. Samtidig gav clickers dem en konkret mulighed for at reflektere over et fagligt spørgsmål og argumentere umiddelbart efter en clickerafstemning.Y derligere nævnte en studerende, at de "sidder fremme $i$ stolen, fordi der er et flow $i$ netop den her undervisning [... ]det er ikke bare en kedelig forelasning, hvor jeg sidder og falder hen, vi doser ikke her... man skulle uddanne undervisere til, hvordan de skal bruge clickers". De pointerede, at de værdsatte variation i præsentations- og gennemgangsformer og at tavle og kridt stadig var teknologier, der var anvendelig, når det drejede sig om at forstå det faglige stof, fordi de kunne følge processen på tavlen. Brug af clickers, mente de studerende, primært var til holdundervisning. "Det vil vere svart at implementere clickers til mindre grupper, man vil jo tit bare blive enige". De studerendes udmelding kan iagttages som en oplevelse af, at når det ikke drejer sig om holdundervisning, men om gruppearbejde, vil det ikke være nødvendigt at inddrage clickers. Det, at kommunikationen foregår face-to-face og mellem få personer, kan reducere kompleksiteten og samtidig øge mulighed for at kunne ytre sig og være en del af dialogen jf. ovenstående.

\section{Faglige forudsatninger og deltagelse}

De studerende skelnede mellem »eliten " og "det brede flertal af studerende i forbindelse med brugen af clickers i undervisningen. »Det vil nok ikke forbedre eliten, men det vil det for det brede flertal. Eliten klarer det selv. Man 
kan godt forestille sig, at det gar for langsomt [...]Clickers scetter farten ned og far flere med «. En studerende nævner i den sammenhæng, at "eliten far mulighed for at forklare de andre, og på den måde kan de også få noget ud af det. Det krover så, at de gider vare med $i$ diskussionerne«, hvilket $i$ følge informanterne ikke altid var tilfældet.

\section{Clickers, en kommunikations- og læringsunder- støttende ressource?}

Casen tager udgangspunkt i clickerbrug i forbindelse med undervisningsformen forelæsning i en holdorganiseret struktur. Denne rammesætning problematiseres ikke af undervisere og studerende, men betragtes snarere som et vilkår.

I denne kontekst, hvor der er mulighed for en fortløbende kommunikation blandt de studerende $\mathrm{i}$ forbindelse med clickerafstemningerne, iagttages clickers som en kommunikations- og læringsressource. Alle studerende kan, set med den anlagte optik, vælge at rette deres opmærksomhed mod kommunikationen og vælge at deltage kommunikativt, det gælder undervisers meddelelse af information, clickerspørgsmål, afstemning, efterfølgende dialog om udfald, udfoldelse af temaet og eventuelle svarrevisioner.

Clickers giver muligheden for at udøve forståelseskontrol, hvilket betragtes som en primær funktion. Det handler såvel om underviseres mulighed for at konstruere viden om egen undervisningspraksis og studerendes faglige progression som om de studerendes mulighed for at koble sig til undervisningens kommunikation. Clickerbrug kan, ifølge de studerende, understøtte deres fortløbende videnskonstruktion, hvis underviser giver dem mulighed for at få afprøvet deres forståelse og tid til at fă korrigeret denne. Det er afgørende, ifølge de studerende, at underviser formår at formulere klare spørgsmål og bruge forskellige typer spørgsmål afhængig af det konkrete faglige mål for undervisningen. Yderligere pointerer de, at det er vigtigt, at underviser ser den clicker-initierede kommunikation som en væsentlig del af undervisningen og bruger denne kommunikation fremadrettet.

Tidsdimensionen aktualiseres primært i en problematisering af det tidskrævende ved at inddrage clickers i undervisningen, da clickers giver anledning til en kommunikationsudfoldelse, hvilket primært betragtes som en fordel for det »brede flertal«.

De studerende gav udtryk for, at de ikke havde noget imod ikke-anonymitet i forhold til underviser, så længe undervisers intentioner var at bruge informationerne til understøttelse af de studerendes faglige udvikling og ikke til kontrol og »credits « for kursusdeltagelse. Der er således afgørende forskelle med hensyn til brugen af clickers og dermed til undervisning og uddannelse, når den refererede litteratur sammenlignes med det danske casestudie.
Denne iagttagelse er endnu et eksempel på, at teknologier stiller sig til rådighed, men ikke i sig selv determinerer brugen. Lidt firkantet formuleret kan clickers bruges som redskab til trivialisering, men clickers kan også bruges ud fra intentionen om at kunne understøtte ikke-trivielle systemers videnskonstruktion. Undervisers pædagogiske og didaktiske kompetencer er afgørende for nytteværdien af clickerinddragelsen.

\section{Konklusion}

I en dansk universitetskontekst og med fokus på holdundervisning presser flere spørgsmål sig på, hvis et redskab som clickers ønskes inddraget. Det drejer sig fx om hvilke fagområder, der kunne have gavn af et sådant redskab? Hvordan clickers kunne tænkes at understøtte udviklingen af konkrete kvalifikationer og kompetencer? Hvordan alle studerende kunne få mulighed for at fortælle, hvorfor de valgte, som de valgte i en clickerafstemning og få fagligt feed-back på dette? Hvilke typer spørgsmål til hvilke faglige mål? Hvilke læringspotentialer for hvem? - Hermed en invitation til fortsat forskning og diskussion.

\section{Referencer}

Barber, M et al (2007). Clicker Evolution: Seeking Intelligent Design in CBE CBE- Life Sciences Education. Vol. 6, Spring 2007, p.1-8.

Bode, M. et al (2009). A Clicker Approach to Teaching Calculus in Notices of the AMS, Vol 56, no. 2.

Bruff, D. (2011). Classroom Response Systems (»clickers») Bibliography. Vanderbilt University, Center for Teaching USA.

Caldwell, J.E. (2007). Clickers in the Large Classroom: Current Research and Best-Practice Tips in CBE-Life Sciences Education. Vol. 6, Spring 2007, p.9-20.

Dufresne, R.J. et al 1996. Classtalk: A classroom communication system for active learning in Journal of Computing in Higher Education 7 p. 3-47

Fies, C et al (2006). Classroom Response System: A Review of the literature in Journal of Science Education and Technology. Vol. 15, No.1 March 2006, p.101-109.

Foerster, H. V. \& Pörksen (2003). Sandheden opfundet af en logner, samtaler for skeptikere. Kbh.: Billesøe \& Baltzer.

Lasry, N. (2008). Clickers or flashcards: Is there realy a difference? In The Physics Teacher. 46/2008 p. 242-244.

Luhmann, N. (2000). Sociale systemer. Kbh.: H. Reitzels Forlag.

Luhmann, N. (2006). Samfundets uddannelsessystem.Kbh.: H. Reitzels Forlag.

MacArthur, J. R.et al (2008). A review of literature reports of clickers applicable to college chemistry classrooms in Chemistry Education Research and Practice. 2008/9, p. 187-195.

Shannon, E.C. et al (1949/1971). The Matematical Theory of Communication. Chicago: University of Illinois Press.

Mazur, E, (1997). Peer Instruction: A user's Manual. Prentice Hall, Upper Saddle River, NJ.

Mazur, E.et al (2001). Peer instruction: Ten years of experience and results in American Journal of Physics 69/2001, p. 970-977. 